\title{
Zróżnicowanie plio-plejstoceńskich Hominidae III. Konsekwencje taksonomiczne i antropogenetyczne
}

\author{
Katarzyna Kaszycka
}

DIFFERENTIATION OF PLIO-PLEISTOCENE HOMINIDS. III. TAXONOMIC AND ANTHROPOGENETIC CONSEQUENCES. The paper discousses the taxonomic conceptions of Australopithecines existing in the literature. In particular it analyses the justness of multi-species hypothesis versus the single-species one. The author favours the conception of two lineages.

Kiedy już calkiem prawdopodobne wydają się odpowiedzi na pytania: które istoty uznać należy za najstarszych przedstawicieli rodziny Hominidae, w jakim czasie żyly, gdzie się pojawily i z jakiej grupy kopalnych naczelnych się wyksztalcily, kiedy zostaly przedstawione [KASZYCKA 1984, 1985] wspólczesne poglądy na temat ich charakterystyki, a materialy kopalne świadczą o dużym zróżnicowaniu form, nasuwa się jeszcze jedno podstawowe pytanie - jakie konsekwencje taksonomiczne i antropogenetyczne plyną z takiego zróżnicowania. Na ten temat oczywiście bylo wiele różnych koncepcji i dlatego w przedstawianej obecnie trzeciej (i ostatniej) części pracy zajęlam się zebraniem poszczególnych interpretacji i przedstawieniem wszelkich argumentów przemawiających za i przeciw nim.

Instytut Antropologii UAM ul. Fredry 10, 61-701 Poznań

\section{Koncepcje wielogatunkowości}

Robert Broom: mnożenie nazewnictwa

W miarę narastania w latach 19361950 liczby znalezisk australopiteków, mnożyly się nadawane im przez odkrywców nowe nazwy systematyczne. W rezultacie, w samej tylko Afryce Południowej wyróżniono cztery rodzaje i sześ́ różnych gatunków plio-plejstoceńskich hominidów: Australopithecus africanus (Taung), Australopithecus prometheus (Makapansgat), Plesianthropus transvaalensis (Sterkfontein), Paranthropus robustus (Kromdraai), Paranthropus crassidens (Swartkrans) i Telanthropus capensis (Swartkrans). Do tego taksonomicznego rozdrobnienia w obrębie australopiteków przyczynil się w glównej mierze R. Broom. 
$\mathrm{Na}$ podstawie fragmentów kości pięciu osobników (!), o numerach katalogowych podanych poniżej, wyodrębnil aż trzy nowe rodzaje i cztery gatunki (dane wg MANNA [1975]):

1) Znalezione w 1936 roku fragmenty jednego osobnika o dwóch numerach katalogowych: TM (STS) 1511 (zlamana szczęka $\mathrm{z}$ prawymi zębami $\mathrm{P}^{4}-\mathrm{M}^{3}$ i lewymi $\mathrm{P}^{3}$. $\mathrm{M}^{2}$, fragment kości potylicznej) i STS 60 (prawie kompletny odlew mózgu) zostaly oznaczone jako Australopithecus transvaalensis, później przemianowane na Plesianthropus transvaalensis.

2) W 1938 roku osobnik TM 1517 (części czaszki z lewymi zębami $\mathrm{P}^{3}-\mathrm{M}^{2}$, żuchwa, fragmenty kości postkranialnych) na podstawie większych trzonowców, dużej żuchwy i bardzo plaskiej części twarzowej czaszki zostal oznaczony jako Paranthropus robustus.

3) W 1948 roku kolejny jeden osobnik, tym razem o czterech numerach katalogowych: SK 2, SK 3, SK 4 (górne zęby) i SK 6 (duży fragment żuchwy z lewymi zębami $\mathrm{M}_{1}-\mathrm{M}_{3}$ ) na podstawie zębów o $50 \%$ większych niż u Paranthropus robustus, zostal oznaczony jako Paranthropus crassidens.

4) Znalezione w 1950 roku dwa osobniki, jeden o numerze katalogowym SK 15 (caly trzon żuchwy $\mathrm{z}$ zębami $\mathrm{M}_{2}-\mathrm{M}_{3}$ po stronie prawej i $M_{1}-M_{3}$ po stronie lewej), drugi o trzech numerach: SK 45 (fragment prawej części trzonu żuchwy i dwa trzonowce), SK 80 (fragment szczęki) oraz SK 847 (polamana czaszka bez kości skroniowych) na podstawie zębów przypominających zęby Homo erectus, zostaly oznaczone jako Telanthropus capensis.

Jak wskazują T. BIELICKI i A. WANKE [1965], za pomocą odpowiednio drobiazgowej analizy morfologicznej nietrudno jest wykazać, że każde znalezisko ma jakieś cechy swoiste, a jeśli w ślad za stwierdzeniem takich różnic idzie zawsze w parze nadawanie nowej nazwy systematycznej jest to dowodem niedostrzegania faktu, że istnieja co najmniej cztery kategorie zmienności morfologicznej o charakterze wewnątrzgatunkowym: wiek, dymorfizm plciowy, polimorfizm i politypowość. Każdy z tych rodzajów zmienności może prowadzić do doszukiwania się różnic gatunkowych tam, gdzie w rzeczywistości wcale ich nie bylo. Poza tym, jak dalej stwierdzają cytowani autorzy, natrafienie na dwie takie czaszki kopalnych przedstawicieli jednego gatunku, które na kilkadziesiąt rozpatrywanych cech wykażą w kilku wyraźne różnice, jest zdarzeniem znacznie bardziej prawdopodobnym, niż trafienie na dwa egzemplarze czaszek nie różniących się od siebie niczym. W świetle powyższych uwag podstawy nazewnictwa Brooma wydają się wątpliwe, a kiedy jeszcze dodamy, że opisane wyżej znaleziska są bardzo niekompletne, z dużą dozą pewności możemy odrzucić proponowaną przez Brooma systematykę jako bezzasadną (patrz tabela 1).

\section{Louis, Mary i Richard Leakey: pomylki interpretacyjne i fluktuacja poglądów}

$\mathrm{Z}$ punktu widzenia chronologii pojawiających się koncepcji, po omówieniu propozycji R. Brooma winniśmy zapoznać się $z$ hipotezą J. Robinsona. Jednak $z$ powodu bezpodstawnego nadawania nowych nazw systematycznych, istotnych pomylek interpretacyjnych i fluktuacji taksonomicznych poglądów rodziny Leakey, ich wlaśnie koncepcje zostaną omówione w tym miejscu.

Mary Leakey w 1959 roku znalazla w Afryce Wschodniej (Olduvai) czaszkę kopalnego hominida, która została ozna- 
Tabela 1. Oznaczenia wieku [MANN 1975] i płci [WolPoFF 1976] dla pięciu "diagnostycznych" wg Brooma osobników

\begin{tabular}{l|l|c|c}
\hline Nr katalogowy & Wyróżniony przez Brooma gatunek & Wiek (w latach) & Pleć \\
\hline & & & \\
TM (STS) 1511 i STS 60 & Plesianthropus transvaalensis & $22 \pm 2$ & męska \\
TM 1517 & Paranthropus robustus & $20 \pm 1$ & żé́ska \\
SK 6, SK 2, SK 3 i SK 4 & Paranthropus crassidens & $15 \pm 1$ & - \\
SK 45, SK 80 i SK 847 & Telanthropus capensis & $34 \pm 3$ & żeńska(?) \\
SK 15 & Telanthropus capensis & $23 \pm 3$ & - \\
& & & \\
\hline
\end{tabular}

czona numerem katalogowym OH 5. Jak pisal L. LEAKEY [1959], pod pewnymi względami przypominala ona czaszkę parantropa (na przyklad obecność grzebienia strzałkowego, względnie prosta przednia krawędź zębodołów, mała wielkość kłów i siekaczy w porównaniu z tylnym uzębieniem, plaskość twarzy), a pod innymi - australopiteka (np. wysokość sklepienia czaszki, glębsze podniebienie, redukcja górnych trzecich trzonowców).W odkrytej czaszce dopatruje się dwudziestu cech specyficznych, które miałyby różnić ją od australopiteka i parantropa znacznie bardziej, niż te dwa rodzaje różnią się między sobą [L. LEAKEY 1959], wyróżnia więc jeszcze jeden nowy rodzaj i gatunek Zinjanthropus boisei. Propozycja taksonomiczna Leakeya okazala się blędna. Zinjantrop nie tylko zostal zaliczony do rodzaju Australopithecus, ale nawet jego odrębność gatunkowa bywa kwestionowana i część autorów stosuje dlań nazwę $A$. boisei, a część $A$. robustus (spotyka się również zapis: A. robustus - boisei). W niektórych cechach (np. w większej krzywiźnie podniebienia, dluższych wyrostkach sutkowatych i innym uksztaltowaniu kości jarzmowych) Leakey dopatrzyl się u zinjantropa wyraźniejszego niż w przypad- ku australopiteków nawiązania do morfologii czaszki ludzkiej. W referacie wygloszonym w listopadzie 1959 roku na sympozjum w Chicago stwierdzil, że Zinjanthropus stoi w bezpośredniej linni ewolucyjnej wiodącej do wspólczesnego czlowieka (za: [BIELICKI, WANKE 1965]), natomiast poludniowo-afrykańskie australopiteki stanowią tylko boczne odgalęzienie ewolucji.

W 1960 roku Louis i Mary Leakey znaleźli, w warstwie leżącej okolo 50 centymetrów poniżej poziomu zinjantropa, szczątki innej formy hominida ( $\mathrm{OH} 7)$. Chociaż osobnik ten (12-letni) mial dużo większe kości ciemieniowe niż OH 5, Leakey stwierdzil tylko, że reprezentuje on hominida $z$ większą pojemnością czaszki [L. LEAKEY 1961a]. Mial to być bezpośredni przodek zinjantropa i dlatego odkrywcy nazwali go pre-Zinjanthropus [TOBIAS 1964]. Jeszcze w tym samym roku jednak, na podstawie porównania zębów, Leakey dochodzi do wniosku, że jego mlody osobnik to nie australopitek, ale bardzo prymitywny przodek Homo [L. LEAKEY 1961b]. W 1964 roku, po odkryciu w Olduvai dalszych szczątków podobnego typu hominidów (OH 4, OH 6, OH 8, OH 13), L. LEAKEY, P. TOBIAS i J. NAPIER [1964] 
wystąpili z tezą o przynależności ich razem ze szczątkami OH 7 do nowego gatunku Homo habilis. Na podstawie fragmentów kostnych wyżej wymienionych osobników autorzy ci przedstawili zestaw cech charakterystycznych nowego gatunku. Byly to między innymi: maly trzon żuchwy (poniżej zakresu australopiteków), mniejsze niż u australopiteków, lecz większe niż u Homo erectus zęby, charakterystyczne mezio-dystalne wydlużenie i labio-lingwalne zwężenie zębów trzonowych (P i M), obojczyk podobny do obojczyka Homo sapiens, charakterystyczna morfologia kości potylicznej, objętość mózgu większa niż u $A$. africanus, ale mniejsza niż u $H$. erectus. Narzędzia z Olduvai bylyby zatem dzielem Homo habilis, a nie zinjantropa (jak pierwotnie sugerowal Leakey). W 1966 roku Louis Leakey oznajmil, ze morfologiczna struktura czaszki Homo habilis dostarcza silnego poparcia dla poglądu, że byl on wlaśnie (a nie Homo erectus) przodkiem Homo sapiens. Wedlug LEAKEY'A [1966] australopiteki reprezentują przodków Homo erectus, który wymarl bezpotomnie.

Syn Louisa - Richard Leakey do 1972 roku uważal, że w rejonie Jeziora Turkana, gdzie prowadzil badania, występowal tylko jeden gatunek hominidów. Ponieważ w Koobi Fora, w przeciwieństwie do stanowisk poludniowo-afrykańskich, masywną czaszkę KNM-ER 406 odkryto w bezposrednim sąsiedztwie gracylnych ER $407 \mathrm{i}$ ER 732, R. LEAKEY [1971, 1972] stwierdzil, że masywnych hominidów nie należy wyodrębniać gatunkowo od gracylnych. Osobniki ER 407 i ER 732 to tylko żeńska forma $A$. robustus - boisei. W 1974 roku, po odnalezieniu dobrze zachowanej czaszki KNM-ER 1813, twierdzenie to zrewidowal. Czaszka ta za bardzo różnila się od czaszek $A$. robustus - boisei, by stanowić tylko jego żeńską wersję. Swym ludzkir uzębieniem przypominala raczej Homo ha bilis, ale z powodu zbyt malej pojemnosic czaszki (okolo $500 \mathrm{~cm}^{3}$ ) R. LEAKEY [1974 1976] uznal ją za reprezentanta $A$. africa nus. Rewizja ta sugerowala, że wspom nianego poprzednio osobnika ER 732 te można uważać za inny gatunek hominid niż osobnika ER 406. Sumując, od 1974 d 1976 roku Leakey dopuszczal występo wanie trzech gatunków wczesnych homi nidów w rejonie Jeziora Turkana.

Od 1976 roku Richard Leakey pisze ju o dwóch gatunkach [LEAKEY, WALKE] 1976; WALKER, LEAKEY 1978; R. LEAKE' 1982]: A. robustus - boisei i Homo habilis przy czym osobniki poprzednio oznaczonı jako $A$. africanus (ER 407 i ER 732) należ! uznać za osobniki żeńskie $A$. robustus boisei, a osobnik ER 1813, ze względu nt podobieństwo do $\mathrm{OH} 13$, zakwalifikowany zostal jako Homo habilis. Różne równie: byly zdania $\mathrm{R}$. Leakeya na temat poslugi. wania się $\mathrm{i}$ wytwarzania przez australo. piteki narzędzi. Najpierw twierdzi [WALKER, LEAKEY 1978], że tylko $A$. robustus nie poslugiwal się narzędziami, z w 4 lata później pisze już, że żaden gatunek australopiteków nie umial wytwarzać narzędzi [LEAKEY 1982].

Po odkryciach w latach siedemdziesiątych na stanowisku Hadar (Etiopia) nowego typu australopiteków i z powodu wielkiego ich podobieństwa do znalezisk $M$. Leakey $z$ Laetoli (Tanzania), D. Johanson wyodrębnil gatunek Australopithecus afarensis. Mary i Richard Leakey oraz A. Walker twierdzą [A new history of Man 1979], że nie tylko ich znaleziska nie reprezentują tej samej populacji co osobniki z Hadar, lecz także, że wśród osobników afarskich różnice morfologiczne są zbyt duże, by można było tlumaczyć je wszystkie dymorfizmem plciowym. M. 
LEAKEY [1981] raczej sugeruje, że hominidy z Hadar przypuszczalnie należą do dwóch gatunków.

\section{John Robinson: dwa rodzaje australopiteków}

Pierwsze opracowania materialu kopalnego poludniowo-afrykańskich hominidów mówily o występowaniu sześciu odrę- bnych gatunków (R. Broom). Dopiero w 1954 roku J. Robinson pierwszy przedstawil hipotezę, że zmienność z pięciu stanowisk może uzasadniać istnienie dwu odrębnych grup: pierwszej obejmującej Taung, Sterkfontein i Makapansgat, a drugiej - Kromdraai i Swartkrans. Pierwsza to Australopithecus africanus, druga Paranthropus robustus (nazwana od pierwszego znaleziska z Kromdraai).

Tabela 2. Wykaz cech, na których oparl się ROBINSON [1963, 1967, 1968] uzasadniając rozdzial poludniowo-afrykańskich australopitekow na dwa (odseparowane na poziomie rodzajowym) taksony

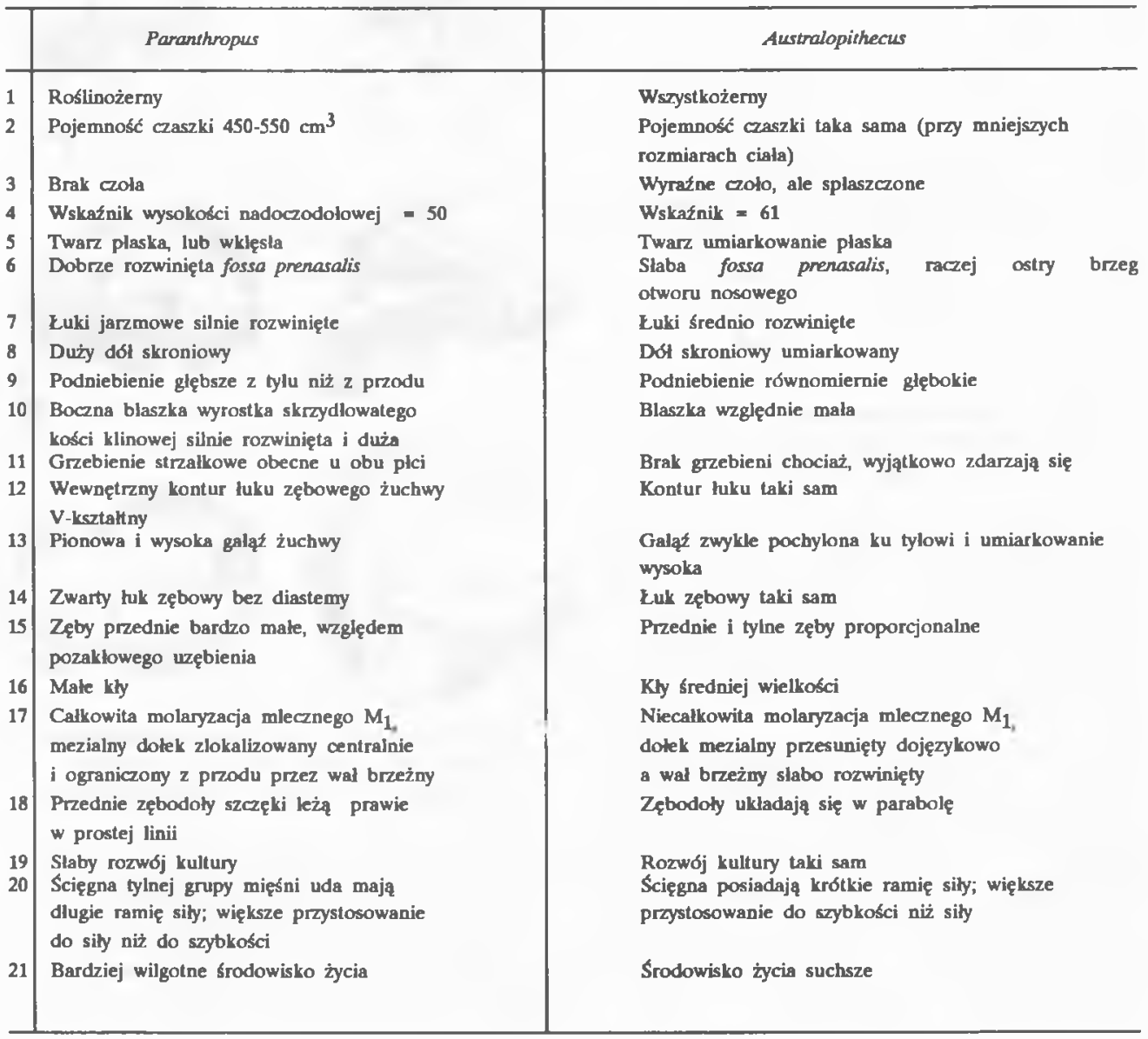


Aby wyjaśnić systemowe różnice, które wg Robinsona różnily obydwa taksony, została zaproponowana hipoteza odmiennych diet. $Z$ początku autor ten sądzil, że żaden $\mathrm{z}$ dwóch taksonów nie daje początku późniejszym hominidom, później stwierdzil, że przodkiem Homo erectus jest Australopithecus africanus, wobec czego zaproponował dla tej formy nazwę Homo africanus [WOLPOFF 1971, 1973].
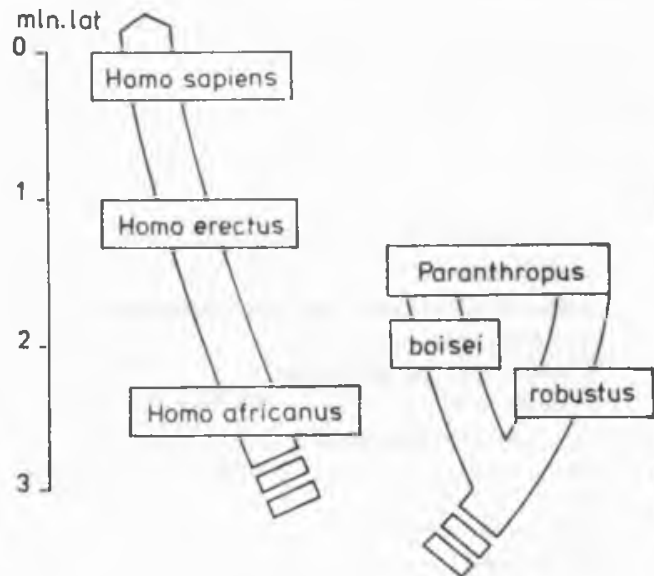

Rys. 1. Schemat ewolucji hominidów przedstawiony przez J. Robinsona w 1972 roku (za: PILbEAM, Gould [1974])

Niezależnie od tego, czy sugestia Robinsona o odmiennych ekologicznych przystosowaniach dwóch taksonów (masywne wyspecjalizowane w pokarmie roślinnym, gracylne jadaly mięso) byla akceptowana, czy też od rzucana, zarzucano mu bezpodstawność rodzajowego odseparowania hominidów. Zwolennicy koncepcji jednego gatunku (przede wszystkim WOLPOFF i BRACE [1975]) krytykowali Robinsona twierdząc, że wyjaśnienie różnic australopiteka i parantropa leży w terminach allometrii, a nie wynika $z$ różnych kierunków adaptacji.

\section{Homo habilis: hipoteza dwóch linii rodowych}

Jak już wspomniano, w 1964 roku, po odkryciach wwąwozie Olduvai, L. Leakey, P. Tobias i J. Napier wystąpili z tezą o istnieniu Homohabilis. Potwierdzeniem jej słuszności byly odkrycia 1972 roku z okolicy Jeziora Turkana, gdzie również w bezpośrednim squsiedztwie $A$. robustus-boisei znaleziono dalsze szczątki tego samego typu hominidów (patrz rys. 2).

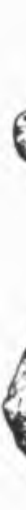
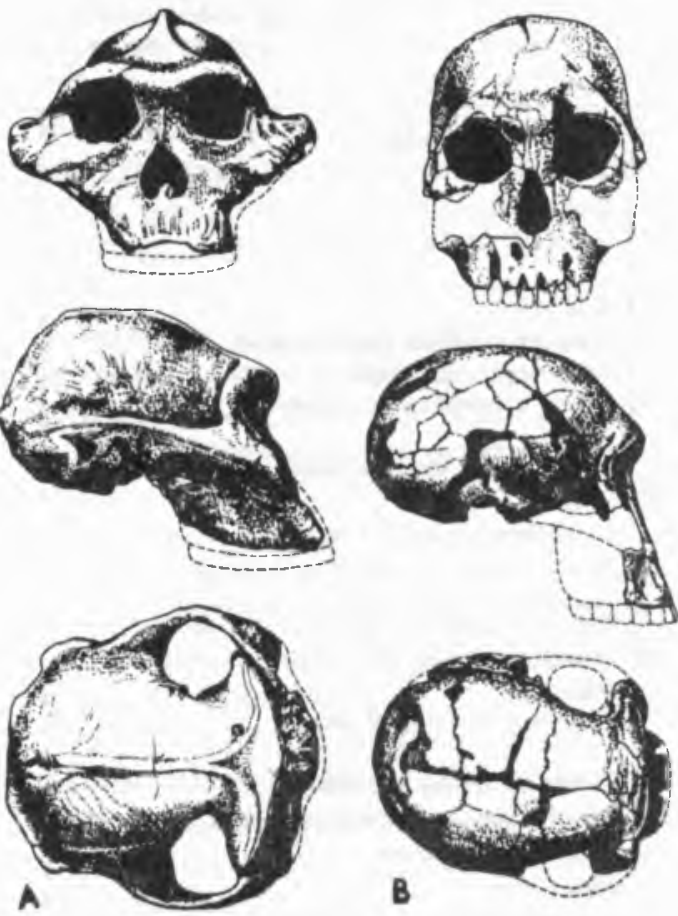

Rys. 2. Znalezione nad Jeziorem Turkana czaszki: A - Australopithecus robustus-boisei KNM-ER 406 i B - Homo habilis KNM-ER 1470

Wywiązala się dyskusja, czy nowy takson rzeczywiście jest innym gatunkiem, a nawet rodzajem, niż australopiteki i gdzie go umieścić w linii rodowej człowieka. Zanim odkryto $H$. habilis, za przodka Homo 
erectus uważano $A$. africanus, natomiast $A$. robustus przedstawiano jako ślepe odgałęzienie drzewa rodowego czlowieka. M. WOLPOFF [1976] i C. BRACE [1972] nie zgadzali się z tą opinią twierdząc, że wszystkie plio-plejstoceńskie hominidy należą do jednego gatunku, a ich duża różnorodność jest spowodowana dymorfizmem płciowym $\mathrm{i}$ indywidualną zmiennością.

$\mathrm{Z}$ pojawieniem się w systematyce czlowiekowatych gatunku Homo habilis rozgorzała dyskusja również na temat liczby gatunków wczesnych hominidów. Jak wskazują D. Pilbeam i M. Zwell [1972],z powodu arbitralności granic między czasowo kolejnymi gatunkami, zasadniczy argument obraca się nie wokól liczby gatunków australopiteków, ale liczby rodowodów. Chociaż wyróżnia się cztery gatunki tych hominidów (A. africanus, $A$. robustus, $H$. habilis, czwarty wg Pilbeama i Zwella to A. boisei; w tej pracy A. robustus boisei), to tylko dwie linie rodowe. Podstawowe pytanie odnosi się więc do tego, ile genetycznie odmiennych gatunków wspólwystępowalo ze sobą.

Jak wskazują wyżej wymienieni autorzy, zanim określi się liczbę linii filetycznych, trzeba rozważyć dwa aspekty problemu: stratygrafię (datowanie znalezisk) oraz dymorfizm plciowy. W przypadku modelu dwurodowego, jeśli jeden lub oba gatunki są silnie dymorficzne pod względem rozmiarów, mogą być problemy z grupowaniem okazów (np. samce, tj. większe osobniki mniejszej linii rodowej mogą pokrywać się rozmiarami z samicami, tj. mniejszymi osobnikami większej linii, jak stwierdzono w przypadku dwóch gatunków makaków). Pomimo tych trudności jest możliwe, jak podają Pilbeam i Zwell, stwierdzenie, która $z$ dwu hipotez: jedno-, lub dwurodowa jest prawdziwa. W tym celu autorzy przeanalizowali pomiary zębów żyjących prymatów i czlowieka wspólczesnego, ze zwróceniem szczególnej uwagi na goryla, u którego dymorfizm plciowy jest największy.

Jak już wspomniano $w$ poprzedniej części pracy [KASZYCKA 1985], u gatunków dymorficznych plciowo (np. goryl, szympans, orangutan, pawian, makak), rozklad wielkości klów (również $\mathbf{P}^{3}$ ) jest dwumodalny. Pozostale zęby mają rozkłady jednomodalne, tak więc nie dają one żadnej informacji czy gatunki są dymorficzne płciowo, czy nie. U wyżej wymienionych gatunków sama wielkość klów jest zwykle wystarczająca do odróżnienia samic od samców. Jest to spowodowane faktem, że różnica w rozmiarach kłów między samcem a samicą jest dużo większa niż 2 odchylenia standardowe (faktycznie często przewyższa 4). W ten sposób stopień pokrywania się wyników samców i samic jest minimalny, a rozklad jest $w$ najwyższym stopniu dwumodalny.

Różnice plci manifestują się nie tylko przez dwumodalny rozkład, ale również przez miarę zmienności w puli osobników męskich i żeńskich. Podczas gdy współczynnik zmienności zębów, których rozkłady pokrywają się u obu plci, jest tylko nieznacznie większy dla polączonych grup płci niż dla każdej z osobna (tabela 3), kly u gatunków wysoce dymorficznych mają wspólczynnik zmienności dla calej puli osobników dwa razy większy niż w przypadku samców lub samic oddzielnie (tabela 4).

Powolując się na swoje badania żyjących prymatów, PILBEAM i ZWELL [1972] stwierdzają, że dymorficzne plciowo gatunki kopalne powinny wykazywać następującą kombinację charakterystyk zębowych:

- pozaklowe uzębienie powinno dawać ciągly, w przybliżeniu Gaussowski rozklad, 
Tabela 3. Wspókzynniki zmienności dhugości $\mathbf{M}^{1} \mathbf{u}$ samcơw i w calej puli osobników (samce i samice), gatunków wykazujących dymorfźm ciçzaru ciała [PILBEAM, ZWELL 1972]

\begin{tabular}{|c|c|c|c|}
\hline Gatunek & $\begin{array}{l}\text { Cleziar ciala } \\
\text { samice/samce (\%) }\end{array}$ & $\begin{array}{c}\text { Wspótczynnity } \\
\text { zmiennodci samo6w }\end{array}$ & $\begin{array}{c}\text { Wspótezynniki } \\
\text { zmiennosed calej puli } \\
\text { caobników ( } \mathrm{O}^{?} \text { i } Q \text { ) }\end{array}$ \\
\hline Papio cynocephalus & so & 4,4 & 5,1 \\
\hline Pongo pygmacus & 55 & 8,0 & 8,6 \\
\hline Gorilla g. gorilla & 60 & 4,0 & 4,8 \\
\hline Cercopithecus ascanius & 70 & 4,9 & 5,8 \\
\hline Pan troglodyes & 85 & 5,8 & 5,4 \\
\hline Symphalangus syndactylus & 90 & 4,5 & 3,9 \\
\hline Homo sapiens & 90 & & 12,6 \\
\hline Hylobates agilis & 95 & 5,9 & 5,0 \\
\hline
\end{tabular}

Tabela 4. Wspótczynniki zmienności długości $\overline{\mathbf{C}}$ u poszczególnych płci i w całej puli osobnikow $\left(\sigma^{\top} \bigcirc\right)$, gatunków wykazujących dymorfizm ciężaru ciala [PILBEAM, ZWELL 1972]

\begin{tabular}{|c|c|c|c|c|}
\hline Gatunel & $\begin{array}{c}\text { Cięzar ciata } \\
\text { samice/samce (\%) }\end{array}$ & $\begin{array}{c}\text { Wspólczynniki } \\
\text { zmiennodci samoów }\end{array}$ & $\begin{array}{l}\text { Współczynniki } \\
\text { zmienności samic }\end{array}$ & $\begin{array}{l}\text { Wspolczynniki } \\
\text { zmienności calej } \\
\text { puli osobnikow }\end{array}$ \\
\hline Papio cynocephalus & 50 & 8,5 & 6,6 & 19,2 \\
\hline Pongo pygmaeus & s5 & 7,4 & 8,8 & 14,5 \\
\hline Gorilla g. gorilla & 60 & 7,7 & 6,9 & 18,3 \\
\hline Macaca nemestrina & 65 & 9,2 & 8,4 & 28,0 \\
\hline $\begin{array}{l}\text { Pan trogladyres } \\
\text { Symphalangus }\end{array}$ & 85 & 9,8 & 4,8 & 11,9 \\
\hline syndactylus & 90 & 8,9 & 6,8 & 10,1 \\
\hline Homo sapiens & 90 & & & 8,8 \\
\hline Hylobates agilis & 95 & 4,6 & 5,1 & 5,1 \\
\hline
\end{tabular}

ze zmiennością niewiele większą niż u niedymorficznych plciowo gatunków; - pomiary klów powinny dawać wyraźnie dwumodalny rozklad, $z$ o wiele większą zmiennością.

Jeśli nie są spelnione oba te warunki, nie można udowodnić dymorfizmu plciowego i nie można tym dymorfizmem wyjaśniać dużej zmienności. W przypadku wspólczesnego czlowieka rozmiary klów zachodzą na siebie u obu plci, podobnie jak wszystkich innych zębów. Tak więc drugie ze wspomnianych wyżej kryteriów nie jest spelnione i powinniśmy oczekiwać malego stopnia dymorfizmu, co rzeczywiście ma miejsce. Jednak $z$ innych powodów, jak piszą Pilbeam i Zwell, uzębienie Homo sapiens wykazuje wysoką zmienność. 
Badając zmienność wczesnych hominidów można przechylić szalę na korzyść hipotezy pojedynczego gatunku, kiedy będziemy porównywać australopiteki nie z gatunkami dymorficznymi plciowo, ale z takimi, u których zmienność uzębienia jest największa ( $H$. sapiens). Wynika $\mathrm{z}$ tego, że wpierw należy ustalić najlepsze wzorce do porównania. Jeżeli prawdziwa jest hipoteza dwu rodowodów, nie otrzymamy prawidlowych wyników, jeśli material $z$ obu linii rozwojowych i kilku okresów polączy się w jedną "próbę". Nie będzie ona miala biologicznej ważności i taka nierozróżniona pula może dobrze wykazywać ciąglość i zachodzący na siebie wzór zmienności. Tą droga "próba" może wykazywać podobieństwo (rzekome) do rozkładów u pojedynczych gatunków. $\mathrm{Z}$ tych wlaśnie powodów Pilbeam i Zwell podzielili material kopalny na wyraźne przedzialy czasowe $\mathrm{z}$ dokładnością do 0,5 mln. lat:

- ponad 2,5 mln. lat: Sterkfontein, Makapansgat, Lothagam, Omo - formacja Usno i Shungura poniżej tufu C;

- 2,5-2,0 mln. lat: Kromdraai, Swartkrans, Omo - formacja Shungura między tufami C i F;

- 2,0-1,5 mln. lat: Olduvai, Jezioro Turkana, Omo - formacja Shungura powyżej tufu F, Peninj;

$-1,5-0,75 \mathrm{mln}$. lat: przedzial ten reprezentuje Homo erectus.

Na rysunkach 3,4 i 5 pokazano rozklady pomiarów zębów plio-plejstoceńskich hominidów $w$ podanych przedzialach czasu. Można zauważyć, że współczynniki zmienności ( $V$ ) rosną $\mathrm{z}$ biegiem czasu

Rys. 5. Histogramy powierzchni $\mathbf{M}_{2}$ u wczesnych hominidow, w podanych przedzialach czasu. Wspólczynnik zmienności $V$ dla Homo sapiens $=15,7$ [PILBEAM,

ZWELL 1972]

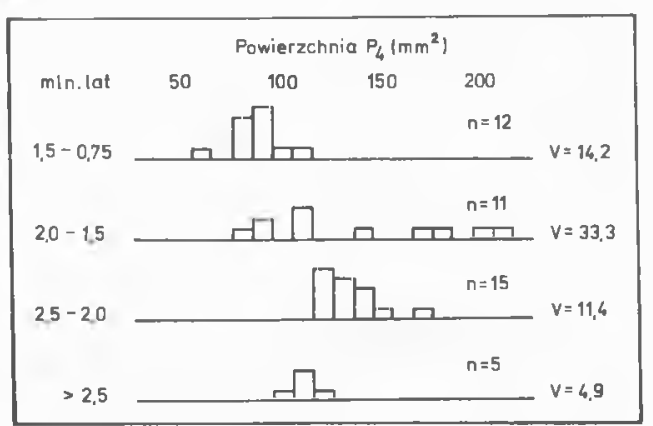

Rys. 3. Histogramy powierzchni $P_{4}$ (dlugość szerokośc) u wczesnych hominidow, w podanych przedzialach czasu. Wspólczynnik zmienności $V$ dla Homo Sapiens $=18,4$ [PILBEAM, ZWELL 1972]

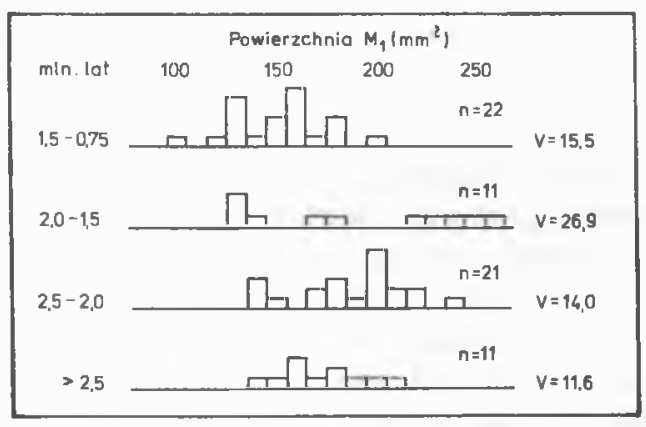

Rys. 4. Histogramy powierzchni $M_{1} u$ wezesnych hominidów, w podanych przedzialach czasu. Wspólczynnik zmienności $V$ dla Homo sapiens $=12,6$ [PILBEAM, ZWELL 1972]

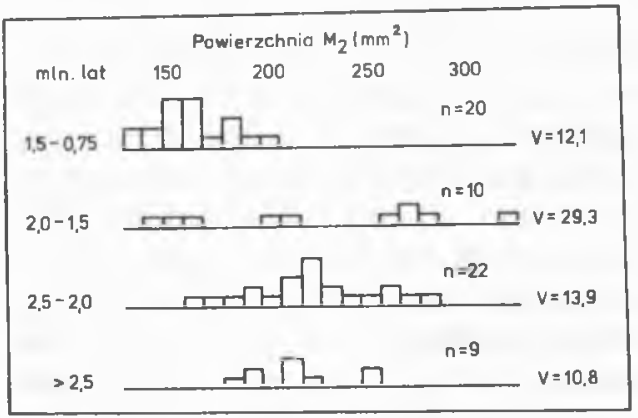




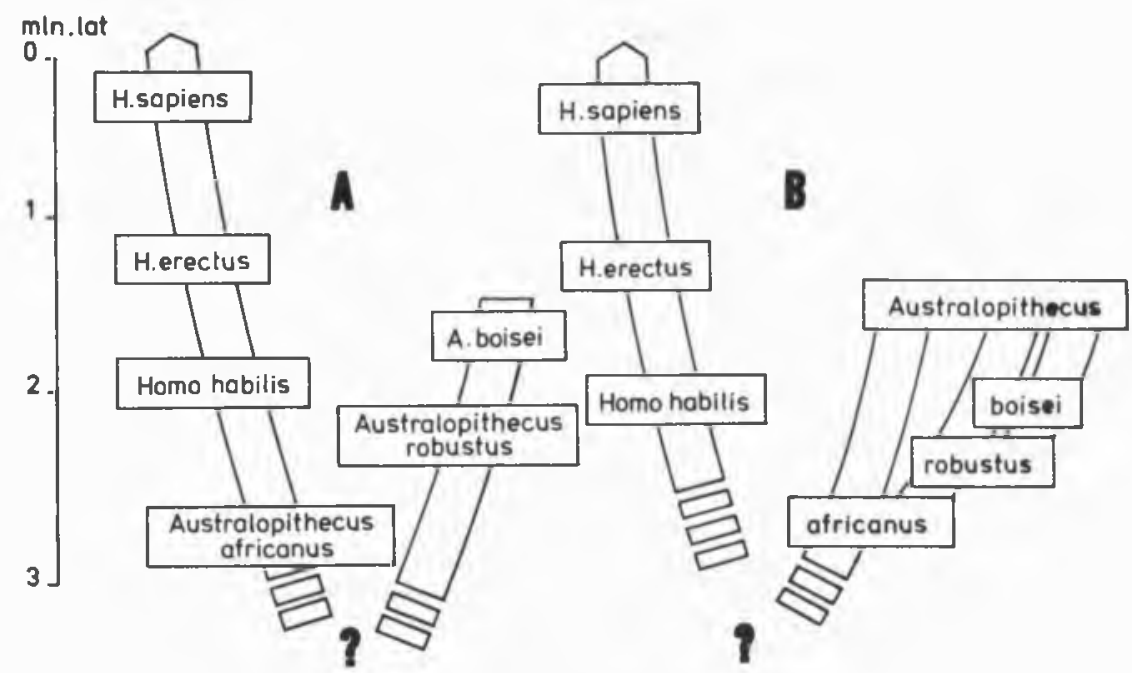

Rys. 6. Dwie wersje ewolucji hominidów przedstawione przez Pilbeama:

A - A. africanus - przodek tylko $H$. habilis [PILBEAM ZWELL 1972]

B - A. africanus - przodek australopiteków masywnych, ale przypuszczalnie również wspólny przodek obu linii rozwojowych [PILBEAM, GOULD 1974]

aż do przedzialu $2,0-1,5 \mathrm{mln}$. lat, gdzie prawie podwajają wartości charakteryzujące Homo sapiens, a potrajają wartości goryla. Testy statystyczne ukazują, że różnice między wczesnymi hominidami a wspólczesnym czlowiekiem są istotne. Do tej uwagi należy jeszcze dodać fakt, że hominidy tego okresu pochodzą tylko z obszaru Afryki Wschodniej. $\mathrm{Na}$ tej podstawie PILBEAM i ZWELL [1972] stawiają wniosek, że kopalne hominidy $\mathrm{z}$ okresu 2,0 - 1,5 mln. lat reprezentuja więcej niż jedną linię rodową, a linie te są reprezentowane we wschodniej Afryce przez gatunki Homo habilis i Australopithecus boisei. Istnienie dwu linii rozwojowych potwierdza również analiza zmienności innych, niż powierzchnia zębów, cech hominidów z omawianego przedzialu czasu: ksztalt zębów, budowa czaszki, pojemność puszki mózgowej. Jest calkiem możliwe również, że rozmiary ciała i wzór dymorfizmu piciowego różnily obydwie linie rodowe. Sumując, Pilbeam i Zwell sugeruja, że $H$. habilis ewoluowal w $H$. erectus, podczas gdy $A$. boisei wymarl (rys. 6).

\section{Donald Johanson i Tim White: Australopithecus afarensis}

Rok 1974 przyniósł paleoantropologii jedno $z$ ciekawszych znalezisk, a mianowicie najbardziej kompletny szkielet osobnika sprzed blisko czterech milionów lat. Jego odkrywcy, D. Johanson, M. Taieb i Y. Coppens, po kilku latach dalszych poszukiwań w tym rejonie (Hadar - Etiopia), znaleźli szczątki kolejnych osobników tego typu. W tym samym czasie na innym stanowisku (Laetoli - Tanzania), prowadzone byly prace wykopaliskowe pod kierownictwem M. Leakey. Porównanie szczątków z obu tych stanowisk wykazalo wyraźne ich podobieństwo. 
$\mathrm{Na}$ podstawie wielu cech prymitywniejszych niż u $A$. africanus, a częściowo nawiązujących do morfologii ramapiteków, Johanson i White w 1979 roku wystąpili z propozycją nadania odkryciom z Hadar i Laetoli nowej nazwy gatunkowej Australopithecus afarensis. Nowy gatunek odznacza się prymitywnością czaszki, zębów, żuchwy i szkieletu postkranialnego. JOHANSON i WHITE [1979] oraz WHITE i in. [1983] w swych pracach przedstawili niektóre najważniejsze anatomiczne cechy materialu.

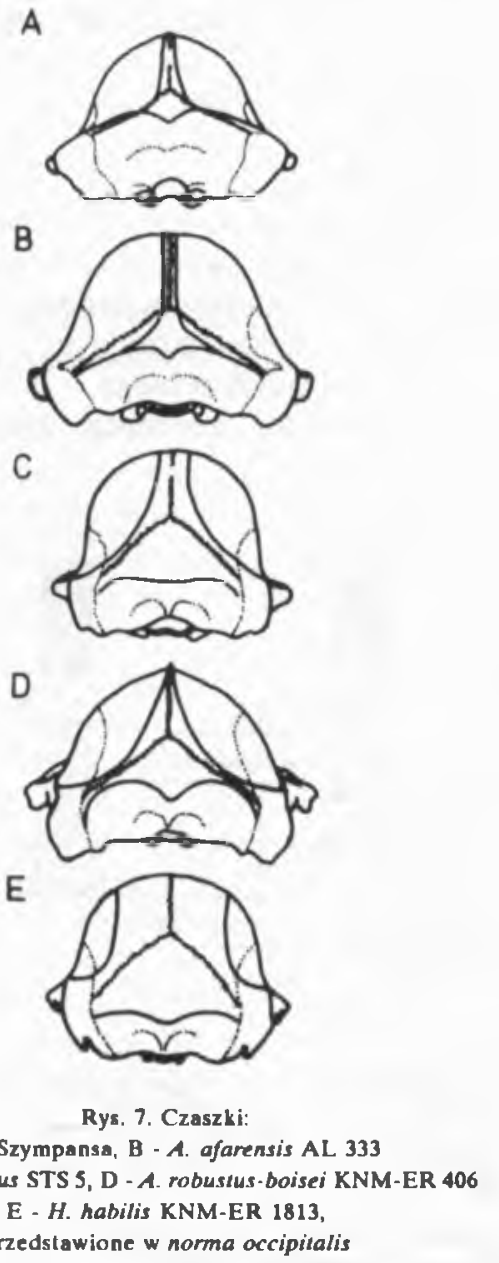

$\mathrm{C} \mathrm{z}$ a s z k a (patrz rys. 7): prawie równolegle biegnące - wzdłuż szwu strzalkowego - kresy skroniowe; kresy karkowe i skroniowe lączą się tworząc grzebienie karkowo-skroniowe (prawdopodobnie występujązarównou osobników męskich, jak i żeńskich); luska kości potylicznej podzielona na malą część górną (stanowiącą część sklepienia) i dużą dolną - pole karkowe; wyrostek sutkowaty i część bębenkowa kości skroniowej wykazują podobieństwo tychże struktur do szympansa; osobniki dorosle mają silny prognatyzm zębodolowy; fossa canina jest bardzo glęboka i szeroka; luk zębowy dlugi, wąski i prosty, a nie paraboliczny; wąskie i plytkie podniebienie.

$\mathrm{Z}$ ę b y: względnie duże przednie zęby $\mathrm{z}$ masywnymi, zakrzywionymi korzeniami; górne przyśrodkowe siekacze bardzo szerokie, w przeciwieństwie do bardzowąskich siekaczy bocznych; kly duże, asymetryczne, wystające ponad luk zębowy: pierwsze górne przedtrzonowce posiadają czasem trzy korzenie; diastemy między zębami: górnymi $\mathrm{I}^{2}$ i $\mathrm{C}$ oraz dolnymi $\mathrm{C}$ i $\mathrm{P}_{3}$; dolne trzonowce, szczególnie pierwszy i drugi, w ogólnym zarysie kwadratowe, a ich wielkość można zapisać jako $\mathbf{M}_{3}>\mathbf{M}_{2}>\mathbf{M}_{1}$. W wielu cechach, uzębienie (tak stale, jak i mleczne) jest pośrednie między Hominidae i Pongidae, a metryczne i morfologiczne dane zębowe nie wykazują występowania w Hadar i Laetoli więcej niż jednej linii rozwojowej.

Szkielet postkranialny: kręgi szyjne mają bardzo dlugie wyrostki kolczyste; kości palców stopy są silnie wygięte; występuje również wiele różnic w kościach palców ręki.

$\mathrm{Na}$ podstawie wyżej wymienionych cech morfologicznych autorzy stawiają wniosek, że hominidy z Hadar i Laetoli to odrębny gatunek, charakteryzujący się silnym dymorfizmem plciowym oraz prymi- 
tywną czaszką i zębami. Caly material należy do pojedynczej linii rodowej - Australopithecus afarensis.

Następną propozycją Johansona i White'a bylo umieszczenie nowego taksonu u podstawy drzewa rodowego czlowieka, jako wspólnego przodka późniejszych hominidów. WHITE, JOHANSON i KIMBEL [1983] przedstawili trzy różne wersje dotyczące ewolucji hominidów (rys. 8). Pierwsza (rys. 8A) zalicza hominidy z Hadar i Laetoli do gatunku $A$. africanus. Jednak morfologiczne różnice między tymi osobnikami a poludniowo-afrykańskim $A$. africanus przewyższają zróżnicowanie wewnątrzgatunkowe i z tego wlaśnie powodu schemat ten nie jest możliwy do przyjęcia. Druga wersja (rys. 8B) uznaje gatunkowe wyróżnienie $A$. afarensis i zachowuje $A$. africanus jako wspólnego przodka dwu linii rozwojowych hominidów. Taki schemat móglby być zaakceptowany, ale za najbardziej prawdopodobny White, Johanson i Kimbel uznają trzeci (rys. 8C).
Wersja trzecia przedstawia $A$. africanus jako przodka $A$. robustus ze względu na ich wzajemne podobieństwo. Jak wskazują zwolennicy tej koncepcji, $A$. africanus pod względem morfologii twarzy, żuchwy i zębów wykazuje podobieństwo zarówno do wcześniejszego $A$. afarensis, jak i do późniejszego $A$. robustus, a znacznie bardziej (pod względem tych cech) różni się od H. habilis.

D. Johanson i T. White, chociaż uznają istnienie aż czterech różnych gatunków plio-plejstoceńskich hominidów, to są zwolennikami koncepcji dwu linii rozwojowych. Nowością ich teorii jest uznanie australopiteka typu afarensis za przodka późniejszych australopiteków i Homo. Zdaniem tych autorów $A$. africanus daje początek linii $A$. robustus i A.robustusboisei, która wymarla bezpotomnie, natomiast linia Homo habilis, poprzez $H$. erectus, doprowadza do powstania czlowieka wspólczesnego.

Z krytyką koncepcji Johansona i
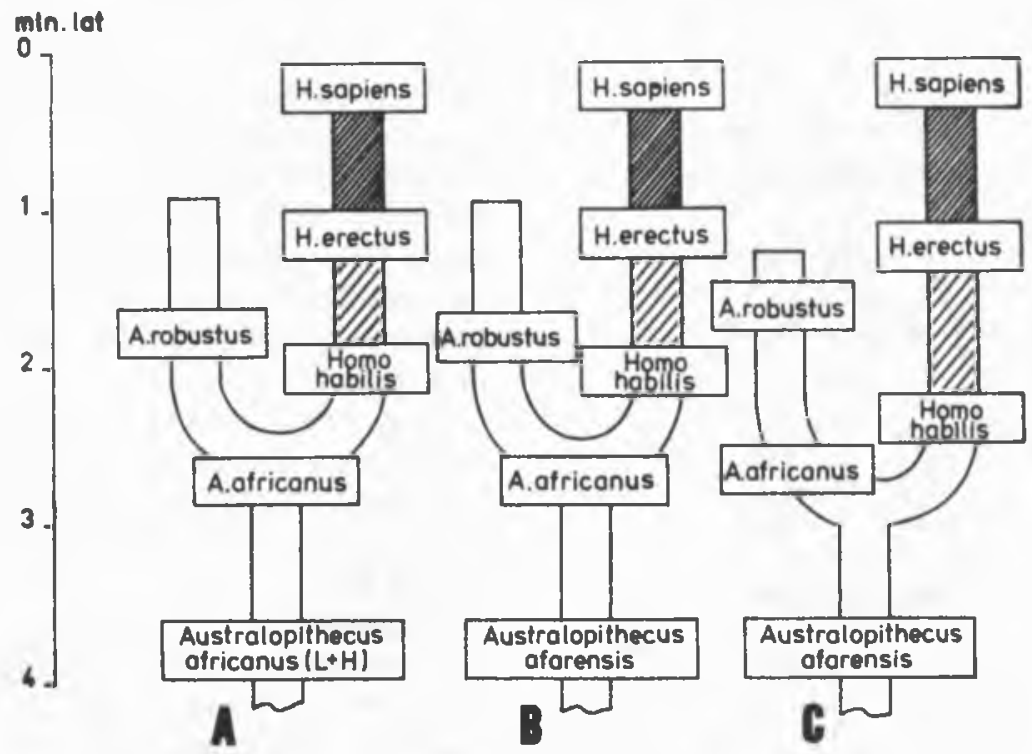

Ry. 8. Flogeneza i taksonomia kopalnych hominidów - trzy wersje [WHTE JOHANSON i KJMBELL 1983]. Komentarz w tekície 
White'a wystapil P. TOBIAS [1980, 1981] twierdząc, że różnice między $A$. africanus (z Afryki Poludniowej) i $A$. afarensis (z Laetoli i Hadar) są zbyt male (jeśli nie liczyć datowania i odleglości geograficznej) by wyróżnić nowy gatunek. W swej pracy z 1980 roku, podaje w wątpliwość diagnostyczność wszystkich kolejnych kryteriów, które mialyby odróżniać $A$. afarensis, dowodząc, że większość z nich jest charakterystyczna dla $A$. africanus, a niektóre - również dla wszystkich australopiteków. Autor ten proponuje hominidom z Laetoli i Hadar nadać rangę podgatunków gatunku Australopithecus africanus (odpowiednio: $A$. africanus tanzaniensis i $A$. africanus aethiopicus).

\section{Koncepcja jednego gatunku i jej konsekwencje teoretyczne}

Zwolennicy koncepcji jednego gatunku to przede wszystkim M. Wolpoff i C. Brace oraz P. Mahler, R. Rosen i J. Wallace. Ich koncepcja opiera się na następujących przesłankach:

1) Duży dymorfizm plciowy plio-plejstoceńskich hominidów, porównywalny ze wspólczesnymi naziemnymi prymatami. Dotyczy to pomiarów szkieletu i zębów [BRACE 1969, 1971; WOLPOFF 1975a, 1975b, 1976].

2) Rewizja hipotezy Robinsona [BRACE 1972, WOLPOFF 1973, WALLACE 1975], z której wynika, że: wiele proponowanych kryteriów użytych do oddzielenia gracylnych i masywnych australopiteków jest nietrafnych; różnice występujące między nimi odpowiadają różnicom rozmiarów ciala; część kryteriów nie może być sprawdzona.

3) Odrzucenie taksonu Homo habilis, z którego jedne osobniki mieszczą się w zakresie zmienności australopiteków, a inne - Homo erectus [BRACE, MAHLER, ROSEN 1972; WOLPOFF, BRACE 1975].

4) Występowanie dużej indywidualnej zmienności, spowodowanej allometrią [BRACE 1972; WOLPOFF 1970, 1973, 1975a].

Ponieważ rozmiary dymorfizmu płciowego omówione zostaly $w$ poprzednich opracowaniach [KASZYCKA 1984, 1985], szerzej przedstawiony zostanie punkt 2. Bardzo szczególową analizę, obejmującą wszystkie kryteria Robinsona, przedstawil WOLPOFF [1973], który podzielil australopiteki na dwie odrębne grupy.

Różnice w absolutnej i relatywnej wielkości klów (w stosunku do zębów trzonowych) byly wg Robinsona "kardynalnym punktem" hipotezy diet. WOLPOFF zbadal zęby, a wyniki przedstawil w tabelach (tab. 5 i 6 ).

Tabela 5. Rozkład częstości powierzchni kłów szczęki i żuchwy $\left(\mathrm{mum}^{2}\right)$ Paranthropus robustus i Australopithecus africanus [WOLPOFF 1973]

\begin{tabular}{c|c|c|c|c}
\hline \multirow{2}{*}{$\begin{array}{c}\text { Powierzchnia } \\
\text { klów }\end{array}$} & \multicolumn{2}{|c|}{ Szczęka } & \multicolumn{2}{c}{ Zuchwa } \\
\cline { 2 - 5 } & $P$ robustus & A. africanus & $P$ nobustus & A. africanus \\
\hline \multirow{2}{*}{$60-69$} & - & - & 4 & - \\
$70-79$ & 6 & 1 & 2 & 3 \\
$80-89$ & 2 & 3 & 2 & 2 \\
$90-99$ & 2 & 2 & 1 & - \\
$100-109$ & 2 & - & - & 2 \\
$110-119$ & 1 & - & - & - \\
$120-129$ & - & 1 & - & - \\
\hline
\end{tabular}


Tabela 6. Rozklad częstości wskaźnika powierzchni $\mathrm{C} / \mathrm{P}^{3}$ szczęki i żuchwy Paranthropus robustus i Australopithecus africanus [WOLPOFF 1973]

\begin{tabular}{l|c|c|c|c}
\hline \multirow{2}{*}{ Wskánik } & \multicolumn{2}{|c|}{ Szczęka } & \multicolumn{2}{c}{ Zuchwa } \\
\cline { 2 - 5 } pow.C/P3 & $P$. mobustus & A. africanus & $P$. mobustus & A. africanus \\
\hline $50-54$ & - & - & 1 & - \\
$55-59$ & - & - & - & - \\
$60-64$ & 2 & - & 3 & - \\
$65-69$ & 1 & - & - & 1 \\
$70-74$ & 2 & - & - & 3 \\
$75-79$ & - & 1 & 1 & 1 \\
$80-84$ & - & - & 1 & 1 \\
$85-89$ & 2 & 2 & - & - \\
\hline
\end{tabular}

wal, że wskaźnik ten odzwierciedla niektóre aspekty morfologii czaszki, a przypuszczalnie również i mózgu [ROBINSON 1967]. Wyniki dla A.africanus uzyskal na podstawie pomiarów czaszki STS 5, a dla P. robustus z rekonstrukcji SK 48. Jak twierdza Wolpoff i Brace, czaszka osobnika o numerze katalogowym SK 48 jest zgnieciona, a dla innej, daleko bardziej kompletnej czaszki $P$. robustus (SK 46), wskaźnik ten wynosi 57. Autorzy ci podejrzewają, żewysokość

$\mathrm{Z}$ tabeli 5 wynika, że jakkolwiek wartości dla $A$. africanus są trochę większe niż dla $P$. robustus, to zakres pokrywania się wyników jest prawie kompletny. Wolpoff zatem wyciąga wniosek, że hipoteza o statystycznych różnicach w absolutnej wielkości klów musi być odrzucona (nawiasem mówiąc, w 1971 roku przedstawil on zupelnie przeciwne wyniki - patrz dyskusja). Dla ukazania międzygrupowych różnic we względnej wielkości klów, Robinson stosowal wskaźnik $\mathrm{C} / \mathrm{P}^{3}$. Tabela 6 wskazuje, że wszystkie gracylne formy mieszcza się w zakresie zmienności masywnych. Nie ma więc powodu, jak pisze Wolpoff, przypuszczać, że wielkość klów w stosunku do pozakłowego uzębienia (jaki reprezentuje $\mathrm{P}^{3}$ ) różnila obie grupy.

Robinson uważal, że u form robustus zębodoly siekaczy i klów leżą w prawie prostej linii, u gracylnych natomiast ukladają się w parabolę. Zdaniem Wolpoffa ksztalty te u wszystkich osobników pokrywają się, a tylko jeden osobnik masywny odbiega pod tym względem od form gracylnych. Robinson dalej stwierdzil istotną rożnicę we wskaźniku wysokości nadoczodolowej między formami $A$. africanus i $P$. robustus (odpowiednio: 61 i 50). Sugero-
STS 5 jest zawyżona.

Wolpoff zaprzecza także możliwości posługiwania się kryterium grzebieni strzalkowych. Podaje przyklady czaszek z grzebieniami u $A$. africanus $\mathrm{i}$ bez-u $P$. robustus. Stwierdza, że uksztaltowanie tych struktur zależy od relacji dwóch czynników: rozmiarów mięśnia skroniowego i dostępnego obszaru na czaszce dla jego przyczepu. U osobników typu robustus, z generalnie większymi rozmiarami ciala, dominuje wplyw allometrii (powiększenie rozmiarów ciała prowadzi do znacznie większego wzrostu aparatu żucia niż rozmiarów czaszki; efektem tego jest zmniejszenie dostępnego obszaru dla przyczepu mięśnia skroniowego) i wydaje się, że to wlaśnie rozmiary ciala determinuja grzebienie. Wolpoff podaje różne wartości kąta nachylenia czola, które u obu grup okazują się podobne: $A$. africanus STS5-35०, STS71$30^{\circ} ; P$. robustus KNM-ER $406-35^{\circ}$, KNM-ER 732 - $32^{\circ}$ i SK $46-25^{\circ}$.

Dolny brzeg otworu nosowego byl kolejną cechą wymienianą przez Robinsona jako kryterium odróżniające formy "smukle" od "masywnych". Wolpoff uważa jednak, że co prawda fossa prenasalis jest częstsza u form robustus, ale cala zmienność form 
gracylnych mieści się w zakresie zmienności robustus. Podobny zakres zmienności występuje zresztą u Homo sapiens, u którego międzypopulacyjna zmienność występowania fossa prenasalis wynosi od 5 do $43 \%$.

Jednakowa pojemność czaszek $A$. africanus i $P$. robustus, przy wyraźnej różnicy rozmiarów ciała, miałaby uzasadniać zdaniem Robinsona - umieszczenie tych istot $w$ dwu różnych taksonach. Wolpoff twierdzi jednak, że z materialów wynika, iż pojemności te różnily się: u masywnych form $519 \mathrm{~cm}^{3}$, u gracylnych $-442 \mathrm{~cm}^{3}$.

Jak już wspomniano w części pracy dotyczącej charakterystyki ekologicznej australopiteków [KASZYCKA 1984], Wolpoff, Wallace i Brace stwierdzili, że czaszkowe i zębowe różnice nie podtrzymują argumentów o zróżnicowaniu diety wczesnych hominidów. Jeżeli różnice takie nawet występowaly, to nie odzwierciedlają się one w budowie osobników poszczególnych grup. Różnice w molaryzacji mlecznych $M_{1}$ oraz $w$ morfologii mezialnego dolka i mezialnego walu brzeżnego, zdaniem Wolpoffa, nie są możliwe do ustalenia (wszystkie zęby są pięcioguzkowe, ze wzorem Y-5). Poza tym dane o typach wzorów opierają się na niewielkiej liczbie osobników - dwa zęby $A$. africanus i osiem $P$. robustus. U czlowieka wspólczesnego spotyka się obydwa typy uksztaltowania korony. Jeśli chodzi o pomiary wysokości galęzi żuchwy, Wolpoff przyznaje, że średnia jest rzeczywiście większa dla form robustus, ale jest to różnica związana $z$ rozmiarami ciala. Pomiary kąta żuchwy sa prawie identyczne dla obu grup - minimalny kąt u $P$. robustus i $A$. africanus wynosi $90^{\circ}$, a średnie odpowiednio - $98^{\circ} \mathrm{i}$ $101^{\circ}$. Wklęslość twarzowa, rozwój luków jarzmowych, dól skroniowy i boczna blaszka wyrostka skrzydlowatego kości klinowej, wedlug zwolenników koncepcji jed- nogatunkowości są cechami związanymi z rozmiarami ciala.

Argumentacje WoLPOFFA [1973] przeciwko hipotezie wielogatunkowości australopiteków można streścić następująco. Autor ten stara się wykazać, że przedstawiane przez Robinsona kryteria służące odróżnianiu form masywnych od gracylnych (patrz tabela 2) dzielą się na:

a) nietrafne (relatywna i absolutna wielkość klów, glębokość podniebienia, obecność popękania szkliwa zębów, polożenie przednich zębodolów szczęki, wskaźnik wysokości nadoczodołowej i kąt galęzi zuchwy),

b) niesprawdzalne (różnice w diecie i zaawansowaniu kultury),

c) dotyczące cech, których zmienność w dużym stopniu lub calkowicie pokrywa się (grzebienie strzalkowe, kąt i splaszczenie czola, rozmiary tylnego uzębienia, morfologia dolnego brzegu otworu nosowego i wysokość galęzi żuchwy),

d) akceptowalne (pojemność czaszki, morfologia pierwszych dolnych mlecznych trzonowców, uksztaltowanie luków jarzmowych, wielkość dołu skroniowego i rozmiary bocznej blaszki wyrostka skrzydıowatego kości klinowej). Kryteria tej grupy jednak nie są wystarczające do podzialu australopiteków na dwa rodzaje, czy nawet gatunki.

Zwolennicy koncepcji zaliczania wszystkich plio-plejstoceńskich hominidów do jednego gatunku odrzucają takson Homo habilis, jako że wedlug nich niczym istotnym się on nie wyróżnia. BRACE, MAHLER i ROSEN [1972] piszą, że:

1) $\mathrm{OH} 7, \mathrm{OH} 16 \mathrm{i} \mathrm{OH} 24$ należą do zakresu zmienności Australopithecus africanus;

2) najbardziej kompletny paratyp Homo habilis - OH 13 nie może być odróżniony od Homo erectus; 
3) fragmenty $\mathrm{OH} 4, \mathrm{OH} 6, \mathrm{OH} 8, \mathrm{OH} 14$, OH 21, OH 27, KNM-ER 730, KNM-ER 731 i KNM-ER 737 nie są wystarczające dla dokonywania rozstrzygnięć taksonomicznych.

Wymienieni autorzy sugerują, że skoro takson Homo habilis jest pozbawiony typowego osobnika, to powinien formalnie zniknąć. WOLPOFF i BRACE [1975] omawiając pracę PILBEAMA i GoULDA [1974], zajmują takie samo stanowisko (chociaż znana im byla już wtedy czaszka KNM-ER 1470). Przyczyną tak dużej zmienności wczesnych hominidów są według tych autorów również reakcje kości na obciążenia, uzasadniające obecność na czaszkach grzebieni i innych wynioslości. Wal podniebienny np. jest wypuklością odpowiadającą szczytowym silom zucia, a boczne rozszerzenie luku jarzmowego i duża fossa temporalis odpowiadają dzialaniu mięśni: żwacza i skroniowego. Nawet większe rozmiary wałów nadoczodolowych mogą wynikać ze zwiększenia naprężeń $w$ tym rejonie (B. ENDO, za: WOLPOFF [1973]).

Podsumowując poglądy zwolenników koncepcji jednego gatunku można stwierdzić, że uważają oni wszystkie plio-plejstoceńskie hominidy za reprezentantów linii prowadzącej do Homo erectus. Jeśli uwzględni się również, że istoty te wykorzystywaly kulturę jako mechanizm adaptacyjny, usprawiedliwione staje się włączenie ich do rodzaju Homo.Natomiast tak dużą zmienność wczesnych hominidów calkowicie wyjaśnia dymorfizm plciowy i allometria.

\section{Dyskusja}

Dwie poprzednie części tej pracy omawiaja przeciwstawne koncepcje dotyczące wczesnych hominidów (nazwanych australopitekami) i ich związek z pochodzeniem czlowieka wspólczesnego. Warto więc zastanowić się nad możliwością wyboru najbardziej przekonywającej.

Koncepcja Roberta Brooma zakladala specjację hominidów na szeroką skalę (każde stanowisko - inny gatunek). Jest to najstarsza koncepcja, dziś w zasadzie zarzucona.

Z licznych hipotez Louisa, Mary i Richarda Leakeyów, potwierdzila się jedynie hipoteza dotycząca odrębności Homo habilis i jego bezpośredniego związku z powstawaniem Homo sapiens; reszta przedstawia fluktuację taksonomicznych poglądów.

John Robinson, na podstawie różnic między hominidami masywnymi i gracylnymi, dzieli je na dwa rodzaje (A. africanus i $P$. robustus) i przedstawia hipotezę różnych przystosowań ekologicznych. Glówne zalożenia Robinsona nie potwierdzily się; wspólcześnie nie uznaje się rodzajowego odseparowania poludniowo-afrykańskich hominidów, chociaż koncepcja ta ma i dziś pojedynczych zwolenników (np. S. ROSEN i T. MC KERN [1971]).

Koncepcje Brooma i Robinsona uznajemy więc za nieaktualne; ich slabe punkty zostaly przedstawione wcześniej. Zajmijmy się zatem szerzej koncepcją jednego gatunku. Przede wszystkim jej slabym punktem jest calkowita dowolność $w$ operowaniu danymi metrycznymi. Potwierdzeniem tej uwagi są różne dane dla tych samych hominidów podane przez Wolpoffa w 1971 i 1973 roku (patrz tabela 7). Dane $z$ tych lat przedstawiaja zupelnie przeciwne wyniki. Podane przez Wolpoffa W 1971 r. zakresy rozkladu częstości powierzchni klów dla $A$. africanus i $P$. robustus nie pokrywają się $(49,7-75,6$. robustus i $75,6-127,0$ 
Tabela 7. Rozklad częstości powierzchni klów żuchwy $\left(\mathrm{mm}^{2}\right)$ $A$. mobustus i $A$. africanus, podany przez. Wolpoffa w 1971 i 1973 roku

\begin{tabular}{l|c|c|c|c}
\hline \multirow{2}{*}{ Powierzchnia } & \multicolumn{2}{|c|}{1971 rok } & \multicolumn{2}{c}{1973 rok } \\
\cline { 2 - 5 } kiow iuchwy & A. mobustus & A. africanus & A. robustus & A. africanus \\
\hline $50-59$ & 4 & - & - & - \\
$60-69$ & 5 & - & 4 & - \\
$70-79$ & 2 & 3 & 2 & 3 \\
$80-89$ & - & - & 2 & 2 \\
$90-99$ & - & 4 & 1 & - \\
$100-109$ & - & 2 & - & 2 \\
$110-119$ & - & - & - & - \\
$120-129$ & - & 1 & - & - \\
\hline
\end{tabular}

Tabela 8. Zakresy pomiarów różnych zębów (mm) A. robusrus i A. africanus [WOLPOFF 1971]

\begin{tabular}{|c|c|c|c|c|}
\hline & A. nobustus & $N$ & A. africanus & $N$ \\
\hline szerokosé $I_{1}$ & $5.5 \cdot 6.9$ & 9 & $6,0-8,1$ & 4 \\
\hline szerokość $\mathbf{I}^{1}$ & $7,3-8,1$ & 8 & $8,2-8,3$ & 2 \\
\hline diugośc $\mathrm{C}$ & $6,9-8.5$ & 11 & $8.3-10.2$ & 12 \\
\hline szerokoséc $\bar{C}$ & $7.2-9.2$ & 11 & $9.0-12.1$ & 12 \\
\hline szerokose $\mathrm{P}^{3}$ & $13,1-17,0$ & 22 & $10,7 \cdot 13,9$ & 15 \\
\hline szerokose $p^{4}$ & $13,7-18,0$ & 23 & $12,2-13,9$ & 15 \\
\hline
\end{tabular}

wyjaśnić ani dymorfizmem plciowym, ani dużą indywidualną zmiennością, ani nawet allometrią.

Jak wskazują WOOD i STACK [1980] oraz CORRUCCINI i CIOCHON [1979], nie wszystkie różnice między $A$. africanus i $A$. robustus dadzą się wytlumaczyć allometrią. Wood i Stack badali allometryczne zależności między: powierzchnią podstawy kla, pierwszym molarem i sumą powierzchni koron wszystkich trzonowców a odleglością glabella-opistocranion oraz zależność między rozmiarami klów a rozmiarami molarów w pięciu taksonach żyjacych prymatów (Homo, Gorilla, Pan, Papio, Colobus). Uzyskane wyniki, autorzy ci następnie porównali z dostępnymi danymi dla australopiteków gracylnych ( $A$. africanus) i masywnych $(A$. robustus i $A$. robustus-boisei). Analizy dotyczące prymatów wskazują. że

dla $A$. africanus), natomiast zakresy podane w 1973 r. prawie calkowicie zachodza na siebie (!). Oczywiście można się zgodzić z poszerzeniem tych zakresów w wyniku kolejnych znalezisk, nie wyjaśnia to jednak pomijania skrajnych wartości $w$ rozkladach. Podobnie rzecz się ma w przypadku pomiarów innych zębów $A$. africanus i $P$. robustus, których zakresy tylko częściowo pokrywają się, lub nie pokrywają się wcale (patrz tabela 8).

Inną slabą strona koncepcji jednego gatunku jest to, że morfologiczne różnice między wspólczesnymi sobie Homo habilis i Australopithecus robustus-boisei sa tak duże (patrz rys. 2), że nie można ich dla każdego wzrostu dlugości glabcllaopistocranion, wskaźnik powiększenia rozmiarów klów przewyższa wskaźnik powiększenia powierzchni trzonowców. Ponadto, powierzchnia podstawy kla jest pozytywnie allometryczna kiedy odniesie się ją bezpośrednio do powierzchni koron trzonowców. Jak wykazali WoOD i STACK [1980], różnice w wielkości klów i molarów między kopalnymi taksonami nie odpowiadają żadnym trendom w porównawczych modelach allometrycznych (taksony masywne maja większe trzonowce, ale mniejsze kly niż takson gracylny). Dane o długości g-op wskazuja. że podczas gdy proporcjonalny wzrost powierzchni koron molarów 
między taksonami odpowiada porównawczym modelom allometrycznym, to zredukowanie rozmiarów klów w taksonie robustus przeczy takim trendom. Podsumowując, redukcja powierzchni podstawy kla w polączeniu ze wzrostem odleglości $g$ - op u australopiteków masywnych nie może być wyjaśniona na podstawie allometrii. CORRUCCINI, CIOCHON [1979], badając wspólczynniki allometrii $A$. africanus i $A$. robustus w porównaniu z prymatami (dotyczy czaszki bez zębów), dochodzą do wniosku, że wwiększości przypadków kierunek różnic między osobnikami OH 5 (tzw. zinjantrop) i STS 5 (A. africanus) odpowiada trendom allometrycznym (szczególnie w budowie twarzy i między twarzo- a mózgoczaszką). Jednakże autorzy ci wskazują, że kilka cech wyraźnie odbiega od wspólczynników allometrii prymatów; są to: ksztalt otworu nosowego, dlugość i szerokość kości nosowych, prognatyzm i powierzchnia foramen magnum.

$\mathrm{Z}$ wymienionych wyżej doniesień (a szczególnie $z$ pracy Wooda i Stacka) wynika, że nie tylko Homo habilis i Australopithecus robustus to rzeczywiście inne gatunki, ale również rodzaj Australopithecus wykazuje zróżnicowanie gatunkowe (A. robustus i $A$. africanus).

Wzorując się na pracy HENNEBERGA [1984], można

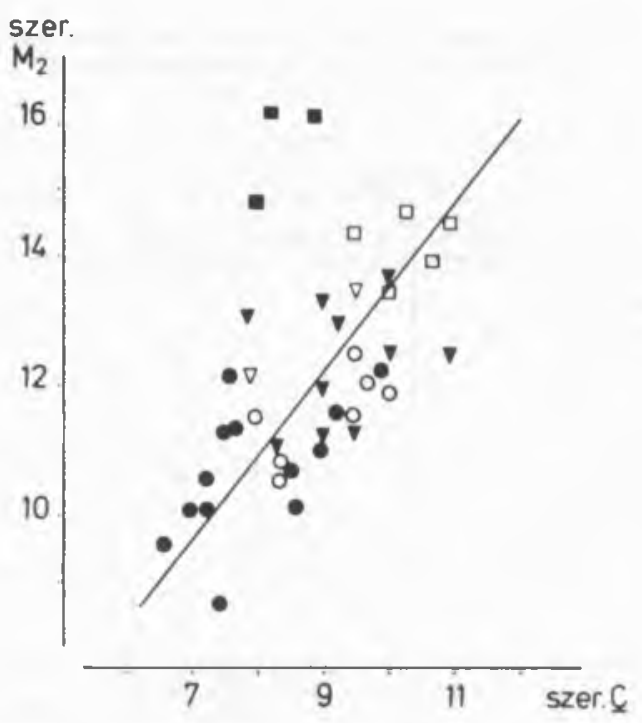

Rys. 9. Zaleinośc pomiędzy zzerokoscią $\mathrm{M}_{2}(\mathrm{~mm})$ a szerokością $\mathrm{C}(\mathrm{mm})$ Czlowiekowatych. Oznaczenia: $A$. robustus, $\square A$ africanus,

$\nabla$ H. habilis, $\nabla$ H.erectus, O Neandertalczyl, Homo sapiens. Opracowanie whasne na podstawie danych z pismiennictwa [WOLPOFF 1971]

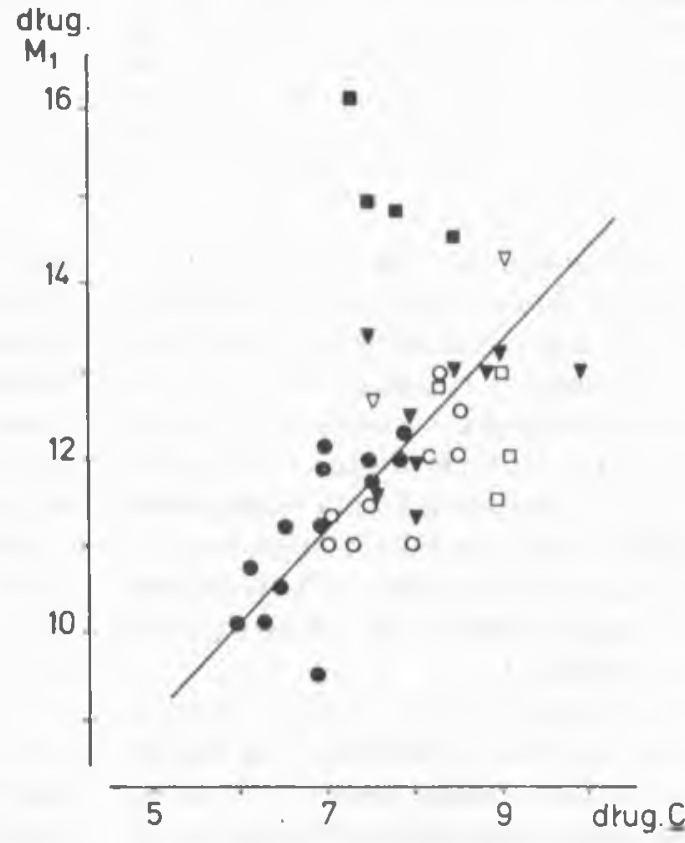

Rys. 10. Zależnósé pomięctzy dhugosciq $M_{1}(\mathrm{~mm})$ i diugoscią $\mathrm{C}(\mathrm{mm})$ czlowiekowalych. Oznaczenia jak na rys. 9. Opracowanie na podstawie danych z piśmiennictwa [WOLPOFF 1971] 


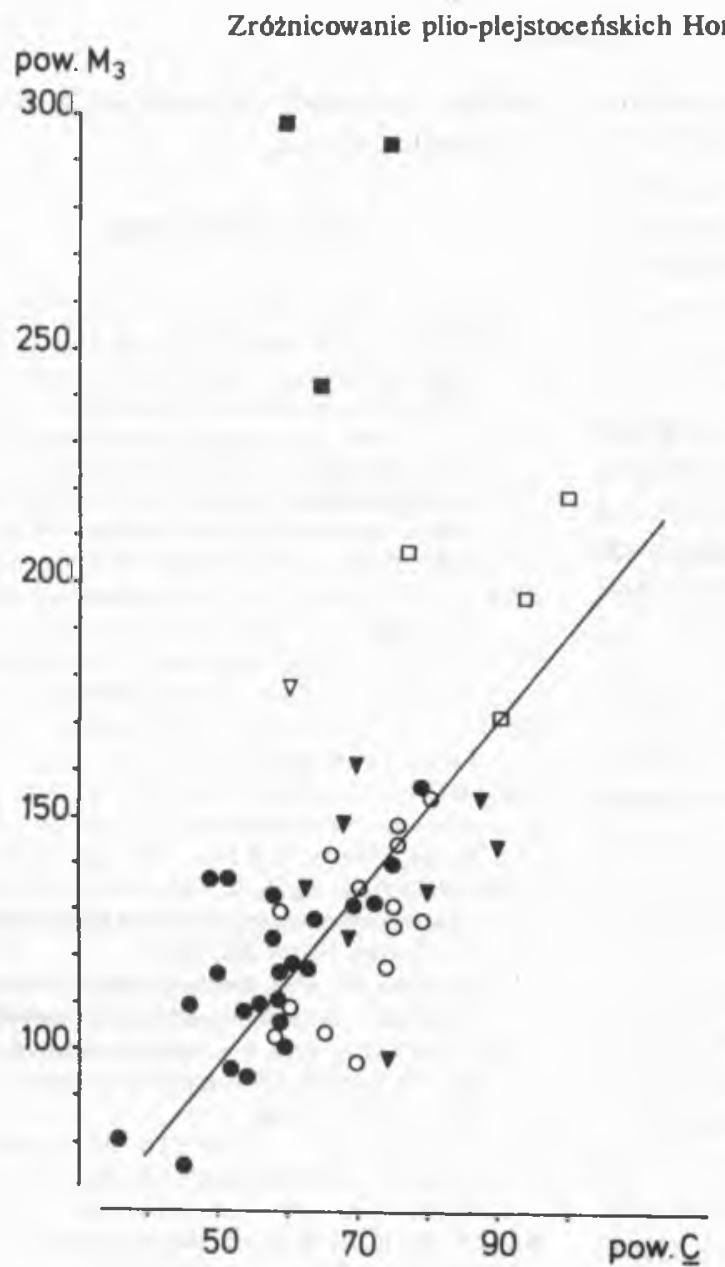

Rys. 11. Zaleznosct pomiędzy powierzchią $\mathrm{M}_{3}\left(\mathrm{~mm}^{2}\right)$ i powierzchnia $\mathrm{C}\left(\mathrm{mm}^{2}\right)$ clowiekowatych. Ozneczenia jak na rvunku 9. Opracowanie na podstawie danych $z$ Diśmiennictwa [WOLPOFF 1971$]$

sporządzić schematy obrazujące stosunki wielkości klów do molarów u $A$. africanus, A. robustus, $H$. habilis, $H$. erectus, $H$. sapiens neandertalensis i $H$. sapiens. Jak wskazują rys. 9 - 11, podczas gdy wartości dla $A$. africanus, $H$. habilis, $H$. erectus, neandertalczyka i $H$. sapiens leżą wzdluż jednej linii, z trendem w kierunku zmniejszania rozmiarów tych zębów w ewolucji, to wartości dla $A$. robustus leżą poza tą linią. Schematy te potwierdzalyby hipotezę Pilbeama i Zwella (i innych zwolenników

koncepcji dwu linii rozwojowych), że australopiteki typu robustus nie należą do naszych bezpośrednich przodków. Warto dodać, że LEUTENEGGER [1972, 1973] na podstawie oszacowanego ciężaru ciala i rozmiarów miednicy mniejszej (w porównaniu ze wspólczesnymi prymatami i czlowiekiem), rozróżnia $A$. africanus i $A$. robustus nie tylko na podstawie morfologii, ale także różnic w dlugości ciąży i ciężarze noworodków.

Koncepcja jednego gatunku posiada sporo wad, ale glówną jej zaletą bylo zwrócenie uwagi na fakt, że różnice morfologiczne niekoniecznie muszą uzasadniać odrębność gatunkową (jak sugerowal Broom), moga bowiem wynikać z dużego zróżnicowania wewnatrzgatunkowego.

Najbardziej wiarygodna wydaje się koncepcja dwu linii rozwojowych, którą reprezentuje np. PILBEAM i ZWELL [1972] (A. afarensis nie byl jeszcze znany), ale i ona ma slaby punkt. Slabym punktem tej koncepcji jest podzial masywnych australopitekow na dwa gatunki: $\boldsymbol{A}$ robustus i $\boldsymbol{A}$. boisei. Ten sam zresztą bląd popelnia TOBIAS [1980, 1981], a w jego przypadku jest to tym bardziej dziwne, że uznaje dwa gatunki australopiteków masywnych, natomiast nie uznaje taksonu $A$. afarensis 
twierdząc, że to tylko podgatunki gatunku A. africanus. Jak wskazują SIMONs [1967] na podstawie morfologii i HOLLOWAY [1972] - na podstawie odlewów endokranium, takie odseparowanie jest nieprawdziwe. Holloway stwierdza, że różnice między $A$. robustus i $A$. boisei są mniejsze niż między wspólczesnym czlowiekiem i neandertalczykiem. Istotne różnice występuja natomiast między masywnymi i gracylnymi australopitekami. Różnice te przekraczają możliwy dymorfizm plciowy. Jak dalej pisze Holloway, samce i samice goryli (również szympansów), które mają tak wysoki stopień dymorfizmu plciowego, ciągle zachowują morfologiczną identyczność odlewów endokranium. Jeżeli skonfrontuje się takie odlewy samca goryla i samca szympansa, można rozpoznać różnice $\mathrm{w}$ ksztalcie $\mathrm{i}$ rozmiarze, przynajmniej tego samego rzędu co między masywnymi i gracylnymi australopitekami.

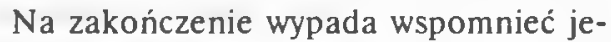
szcze jedną koncepcję, a mianowicie koncepcję JOHANSONA i WHITE'a [1979]. Zaklada ona również istnienie dwu linii rozwojowych hominidów, z tym, że u podstawy drzewa genealogicznego czlowieka autorzy ci umieszczaja gatunek $A$. afarensis, reprezentowany osobnikami z Laetoli i Hadar.

Dyskusje na temat systematycznych powiązań plio-plejstoceńskich hominidów nie są zakończone. Nie można jeszcze rozstrzygnąc gdzie umieścić $A$. africanus: czy jako wspólnego przodka $H$. habilis i $A$. robustus (np. PILBEAM, GOULD [1974], TOBIAS [1980], SKELTON i in. [1986]), czy tylko $H$. habilis (np. PILBEAM, ZWELL [1972], BOAZ [1983]), czy wreszcie jako przodka tylko $A$. robustus (np. WHITE i in. [1983]). Wydaje się jednak, że najbardziej przekonywająca jest koncepcja dwu linii rozwojowych, wedlug której linia $A$. robustus stanowi boczny tor ewolucji, a linia $H$. habilis doprowadza do powstania czlowieka wspólczesnego.

\section{Piśmiennictwo}

A new history of man, 1979, New Scientist 81, 319

BIELICKI T., A. WANKE, 1965, Wczesnoplejsloceńskie hominidy z Olduvai i zagadnienie "bocznych odgatęzieñ" w ewolucji czlowieka, Kosmos 14 A, 31-43.

BOAZ N. T., 1983, Morphological trends and phylogenetic relationships from Middle Miocene hominoids to Late Pliocene hominids, [w:] New Interpretations of Ape and Human Ancessry, R. L. Ciochon, R. S. Corruccini (eds.), Plenum, New York, 705-720.

BRACE C.L., 1969, The Australopithecine range of variation, Am. J. Phys. Anthrop. 31, 255.

BRACE C. L., 1971, Sex, inadequacy and Ausiralopithecine identity conflicts, Am. J. Phys. Anthrop. 35, 274.

BRACE C. L., 1972, Sexual Dimorphism in Human Evolution, Yearbook of Phys. Anthrop. 16, 31-49.

BRACE C. L., P. E. MAHLER, R.B. RosEN, 1972, Tooth Measurements and the Rejection of the Taxon "Homo habilis", Yearbook of Phys. Anthrop. 16, 50-68.

CoRruCcini R. S., R. L. CiOChON, 1979, Primate facial allometry and interpretations of Australopithecine variation, Nature 281, 62-64.

HENNEBERG M., 1984, Ewolucja mózgu a inteligencja: przekonania, uprzedzenia, fakty, (maszynopis).

HOLLOWA Y R. L., 1972, New Australopithecine Endocast, SK 1585, from Swartkrans, South Africa, A m, J, Phys. Anthrop. 37, 173-185.

Johanson D. C., T. D. WhITE, 1979, A Systematic Assessment of Early African Hominids, Science 203, 321-330.

KASZYCKA K., 1984, Zróżnicowanie plio-plejstoceńskich Hominidae. I. Charakterystyka morfologiczna i ekologiczno, Przegląd Antrop. 50, 277-297.

KASZYCKA K., 1985, Zróżnicowanie plio-plejstoceniskich Hominidae. II. Dymarfizm piciowy, Przegląd Antrop. $51,65.77$

LEAKEY L. S. B., 1959, A New Fossil Skull from Olduvai, Nature 184, 491-493.

LEAKEY L. S. B., 1961a, New Finds at Olduvai Gorge, Nature 189, 649-650.

LEAKEY L. S. B., 1961b, The Juvenile Mandible from Olduvai, Nature 191, 417-418.

LEAKEY L. S. B., 1966, Homo habilis, Homo erectus and the Australopithecines, Nature 209, 1279-1281.

LEAKEY L.S.B., P.V. TOBIAS, J. R. NAPIER, 1964, A New Species of the Genus Homo from Olduvai Gorge, Nature 202, 7-9.

LEAKEY M. D., 1981, Tracks and rools, [w:] The Emergence of Man, R. Soc., London, 95-102

LEAKEY R. E., 1971, Further Evidence of Lower 
Pleistocene Hominids from East Rudolf, North Kenya, Nature 231, 241-245.

LEAKEY R. E., 1972, New Fossil Evidence for the Evolution of Man, Social Biology 19, 99-114

LEAKEY R. E., 1974, Further evidence of Lower Pleistocene hominids from East Rudolf, North Kenya, 1973, Nature 248, 653-657.

LEAKEY R. E., 1976, Hominids in Africa, American Scientist 64, 174-178.

LEAKEY R. E., 1982, Human Origins, Lodestar Books, New York.

LEAKEY R. E., A. C. WALKER, 1976, The Australopithecus, Homo erectus and single species hypothesis, Nature 261, 572-574.

LEUTENEGGER W., 1972, Newborn Size and Pelvic Dimensions of Australopithecus, Nature 240, 568-569.

LEUTENEGgER W., 1973, Gestation Period and Birth Weight of Ausiralopithecus, Nature 243, 548.

MANN A. E., 1975, Some Paleodemographic Aspects of the South African Australopithecines, Univ. of Pennsylvania Publ. in Anthropol.1.

PILBEAM D., S. J. GOULD, 1974, Size and Scaling in Human Evolution, Science 186, 892-901.

PILBEAM D., M. ZWELL, 1972, The Single Species Hypothesis, Sexual Dimorphism, and Variability in Early Hominids, Yearbook of Phys. Anthrop. 16, 69-79.

ROBINSON J.T., 1963, Ausiralopithecines, Culture and Phylogeny, Am. J. Phys. Anthrop. 21, 595-605.

ROBINSON J. T., 1967, Variation and the Taxonomy of the Early Hominids, [w:] Evolutionary Biology 1, T. Dobzhansky, M. Hecht, W. Steere (eds.), New York, 69-100

ROBINSON J. T., 1968, Skull of Early Hominid. The Cranium and Maxillary Dentition of Australopithecus (Zinjanthropus) boisei, Nature 219, 981-982.

Rosen S. I., T. W. MC KERN, 1971, Several Cranial Indices and Their Relevance to Fossil Man, Am. I. Phys. Anthrop. 35, 69-73.

SIMONS E. L., 1967, The Significance of Primate Paleontology for Anthropological Sudies, Am. J. Phys. Anthrop. 27, 307-332.

SKELTON R. R., H. M. MC HENRY, G. M. DRAWIJORN, 1986, Phylogenetic Analysis of Early Hominids, Current Anthrop., 27, 21-43.

Toblas P. V., 1964, The Olduvai Bed I Hominine with
Special Reference to It's Cranial Capacity, Nature 202, 3-4.

Toblas P. V., 1980, "Australopithecus afarensis" and $A$. africanus: critique and an altemative hypothesis, Palaeont. afr., 23, 1-17.

TOBIAS P. V., 1981, The emergence of man in Africa and beyond, [w:] The Emergence of Man, $\mathbf{R}$. Soc., London, 43-56.

WALKER A., R. E. LEAKEY, 1978, The Hominids of East Turkana, Scientific American 239, 44-56.

WALlace J. A., 1975, Dietary Adaptations of Australopishecus and Early Homo, [w:] Paleoanthropology. Morphology and Paleoecolog;, R. H. Tuttle (ed.), Mouton, Chicago.

WhiteT.D., D.C. JohANSON, W. H. KiMBEL, 1983, Australopithecus africanus. Its Phyletic Position Reconsidered, [w:] New Interpretations of Ape and Human Ancestry, R. L. Ciochon and R. S. Corruccini (eds.), Plenum Publ. Corpor., New York, 721-780.

WOLPOFF M. H., 1970, The Evidence for Multiple Hominid Taxa at Swarkrans, American Anthropologist 72, 576-607.

WolPOFF M.H., 1971, Mesric Trends in Hominid Densal Evolution, Case Western Reserve Studies in Anthropol. 2.

WOLPOFF M.H., 1973, The Evidence for Two Australopithecine Lineages in South Africa, Yearbook of Phys. Anthrop. 17, 113-139.

WOLPOFF M.H., 1975a, Some Aspects of Human Mandibular Evolution, [w:] Determinants of Mandibular Form and Growth, J. Mc Namara Jr. (ed.). Center for Human Growth and Development, Ann Arbor, Michigan.

WOLPOFF M. H., 1975b, Sexual Dimorphism in the Australopithecines, [w:] Paleoanthropology. Morphology and Paleoecology, R. H. Tuttle (ed.), Mouton, Chicago.

WOLPOFF M. H., 1976, Some Aspects of the Evolution of Early Hominid Sexual Dimorphism, Current Anthropology 17, 579-606.

WOLPOFF M. H., C. L. BRACE, 1975, Allomern and Early Hominids, Science 189, 61-63.

WoOD B. A., C. G. STACK, 1980, Does Allomery Explain the Differences Between "Gracile" and "Robust" Australopithecines?, Am. J. Phys. Anthrop. 52, 55-62.

Maszynopis nadeslano w lipcu 1985 r.

\section{S u m m a r y}

This work presents the final part of a cycle of articles among which the two latter ones discussed the morphology, ecology and scxual dimorphism of early hominids called Australopithecines. The present part evaluates two different interpretations of hominid phylogeny: multi-species hypothesis and the single species one. 
The proposals of R. Broom; Louis, Mary and Richard Leakey; J. Robinson, D. Pilbeam and M. Zwell; and D. Johanson and T. White have been discussed. Attention has been concentrated on cases of unjustified multiplication of terminology (Table 1), essential erroneous interpretations (e.g. Zinjanthropus), and fluctuations of taxonomic views, the dietary hypothesis (Table 2, Fig. 1), conceptions following from the discovery of Homo habilis (Fig.6), and the discoveries from Hadar and Laetoli (Fig.7, 8). The above hypotheses are opposed by the proposal of $\mathrm{M}$. Wolpoff and $\mathrm{C}$. Brace basing mainly on the data about sexual dimorphism of Plio-Pleistocene hominids, a high allometric variability, reevaluation of J. Robinson's hypothesis and on the rejection of the taxon Homo habilis.

In the discussion the author deals more extensively with the single species hypothesis, indicating its weak points (option in the use of metric data - Table 7, and interpretation through allometry) but pointing out its merits as well. In the conclusion the author states that the discussion concerning the phylogenetic systematics of Plio-Pleistocene hominids has not been terminated yet. In the present state of studies the most convincing seems to be the hypothesis of two lineages proposed among others by Pilbeam and Zwell, and Johanson and White. According to them the direct ancestor of the modern man is the form of Homo habilis, while Australopithecus mobustus represents a sidebranch of the phylogenetic tree. The problem which of the Plio-Pleistocene forms was the common ancestor of the mentioned lineages requires a solution. 